\title{
Preliminary Study of the Spiders Inhabiting Ornamental Plants in Orman Garden, Egypt (Arachnida: Araneae)
}

\author{
Mona M. A. Ghallab \\ Plant Protection Research Institute, Agriculture Research Center, Egypt
}

\begin{abstract}
A survey on spiders associated with foliage of two ornamental plants (Lantana shrubs and Croton trees) was carried out in the Orman garden, Giza. Numbers of collected spiders were pooled and analysed for species diversity using Shannon-Wiener Index, evenness, Simpson Index and Sørensen Quotient of Similarity. A total of 567 spiders were grouped in 13 families belonging to 34 genera Lantana shrubs received 263 individuals representing 27 species, 25 genera, of 13 families, while 304 individuals were collected from Croton trees belonged to 22 species and 21 genera, of 10 families. Five families represented $85.2 \%$ of the total collected.spiders, these are Miturgidae, Philodromidae. Salticidae, Theridiidae and Araneidae. The other remaining families represented $14.6 \%$ of the total catch. Guild structure analysis revealed seven feeding groups namely, stalker, ground runner, foliage runner, ambusher, orb web spiders, space weaver and wandering sheet spiders. This grouping varied in relation to the structural quality of vegetation; the foliage runner, stalker and ambusher spiders were the dominant feeding guilds on Lantana, while the orb web spiders, the space weavers and the ambushers were the dominant feeding guilds on Croton.
\end{abstract}

Key Words: Araneae, Diversity, Foraging guild, Orman garden, Shannon Wiener Index, Simpson Index, Similarity, Sørensen Quotient.

\section{INTRODUCTION}

The Orman botanical garden is located west of the Nile River and east of Cairo University in Giza governorate. It was founded in 1875 by Khedive Ismail who commissioned its landscaping to the French designer Gustave de la Chevalerie who used a collection of great diversity of exotic rare trees and plants imported from South America, India, Madagascar and Australia. Its area at that time was about 60 acres, but later large areas were taken and added to Giza Zoo. The area now is about 30 acres. In 1917, it was put under the Ministry of Agriculture management.

In the garden, there is a rocker garden, of two acres, where succulents and many rare cactus species, a pond with water and marsh plants among which are found the two most famous aquatic plants in ancient Egypt, Papyrus and Lotus. There is also a rose garden, of three acres, and bunches of rare species of Ficus, Paim, Bamboo, conifers and the only red wood tree in Egypt.

Considering the importance of spiders in the natural suppression of many insect and mite pests and as bio-indicators, urgent efforts are needed to understand their diversity (Sudhikumar et al., 2005). Previous studies demonstrated that spiders inhabiting different strata of habitats may respond differently to changes in environmental factors (Hermann et al., 2010).

In Egypt, researchers have provided descriptions of spider species abundance or composition in a variety of agro-ecosystems (Sallam, 2002; Habashy et al., 2005). Others provided quantitative observations on the abundance and daily activity of spiders (Hussein, 1999; Ragab, 2003) or studied the spider biology, the predation events and the impact of different insecticides or fertilization on spiders (Hussein et al., 2003; Hendawy \& Abul-Fadl, 2004; Sallam et al., 2010; Mahmoud et al., 2011).

This study shed light on the taxonomic spider assemblages "family guild composition" from two ornamental plants of different structural composition and to the spider communities, concerning relative abundance, species richness, guild composition, Shannon-Wiener index (H'), Simpson index (S), and evenness (e) to quantify the community structures of spiders among the two different vegetation types. These calculations were based upon spider species compositions of the sampling.

\section{MATERIALS AND METHODS}

\section{Site description and sampling:}

Survey and seasonal abundance of spiders were studied in the Orman garden, Giza, Egypt for a whole year. Two ornamental plants of different structures and compositions were selected. The first was a set of Croton trees (Codiaeum variegatum L.) in a corner of the garden near a lake, composed of 28 trees of $2-3.5 \mathrm{~m}$. height, act as woodland habitat. The second was Lantana shrubs (Lantana camara L.) found as hedge about $35 \mathrm{~m}$ longs planted on sandy soil and bordered one side of a small garden of cactus and succulent plants. 
Table (1). Species richness of the collected spiders inhabiting Lantana, May 2009 - April 2010

\begin{tabular}{|c|c|c|c|c|c|c|}
\hline Families \& Species & $\hat{0}$ & 우 & $\mathbf{J}$ & $\mathbf{z}$ & Total & $\%$ \\
\hline Miturgidae & & & & & \multirow{2}{*}{81} & \multirow{2}{*}{30.80} \\
\hline Cheiracanthium $\mathrm{sp}$. & 5 & 5 & 71 & 81 & & \\
\hline \multicolumn{5}{|l|}{ Saltícidae } & \multirow{14}{*}{67} & \multirow{14}{*}{25.47} \\
\hline Thyene imperialis & 4 & 5 & 27 & 36 & & \\
\hline Hasarius adansoni & 2 & 2 & 2 & 6 & & \\
\hline Pseudicius spiniger* & 2 & - & - & 2 & & \\
\hline Pseudicius sp. ${ }^{*}$ & - & 2 & 1 & 3 & & \\
\hline Ballus sp. & - & 2 & 4 & 6 & & \\
\hline Heliophanillus fulgens sp.* & - & 1 & - & 1 & & \\
\hline Euophrys sp. & - & 2 & 1 & 3 & & \\
\hline Euophrys granulata?* & 1 & - & - & 1. & & \\
\hline Plexippus paykulli* & & 1 & - & 1 & & \\
\hline Plexippus sp. & 1 & - & - & 1 & & \\
\hline Synageles dalmaticus ?* & 1 & 2 & - & 3 & & \\
\hline Heliophanus sp.* & - & 1 & - & 1 & & \\
\hline Unidentified species* & - & - & 3 & 3 & & \\
\hline \multicolumn{5}{|l|}{ Philodromidae } & \multirow{3}{*}{46} & \multirow{3}{*}{17.49} \\
\hline Philodromus sp. & 6 & 20 & 18 & 44 & & \\
\hline Thanatus albini & - & 2 & - & 2 & & \\
\hline \multicolumn{5}{|l|}{ Thomisidae } & \multirow{3}{*}{19} & \multirow{3}{*}{7.22} \\
\hline Thomisus spinifer & 5 & 3 & 4 & 12 & & \\
\hline Thomisus sp. & 1 & 2 & 4 & 7 & & \\
\hline \multicolumn{5}{|l|}{ Theridiidae } & \multirow{2}{*}{19} & \multirow{2}{*}{7.22} \\
\hline Kochiura aulica & 4 & 6 & 9 & 19 & & \\
\hline \multicolumn{5}{|l|}{ Lycosidae } & \multirow{5}{*}{13} & \multirow{5}{*}{4.94} \\
\hline Allocosa sp. & - & 2 & - & 2 & & \\
\hline Trochosa sp. & - & 4 & - & 4 & & \\
\hline Pardosa sp. & 1 & - & 3 & 4 & & \\
\hline Unidentified species & - & - & 3 & 3 & & \\
\hline \multicolumn{5}{|l|}{ Araneidae } & \multirow{3}{*}{5} & \multirow{3}{*}{1.90} \\
\hline Neoscona sp. & - & 1 & 1 & 2 & & \\
\hline Unidentified species & - & 1 & 2 & 3 & & \\
\hline \multicolumn{5}{|l|}{ Dysderidae } & \multirow{2}{*}{4} & \multirow{2}{*}{1.52} \\
\hline Dysdera crocota* & - & 3 & 1 & 4 & & \\
\hline Oxyopidae & & & & & & \\
\hline Oxyopes sp.* & - & 1 & 2 & 3 & 3 & 1.14 \\
\hline Uloboridae & & & & & ? & \\
\hline Uloborus walkenaerius & - & 1 & 1 & 2 & 2 & 0.76 \\
\hline Dictynidae & & & & & & \\
\hline Nigma sp. ${ }^{*}$ & - & 1 & 1 & 2 & 2 & 0.76 \\
\hline Hersiliidae & & & & & & \\
\hline Hersilia sp.* & - & 1 & - & 1 & 1 & 0.38 \\
\hline Linyphiidae & & & & & 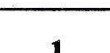 & 038 \\
\hline Bathyphantes sp.* & - & - & 1 & 1 & 1 & 0.38 \\
\hline Total & 33 & 71 & 159 & 263 & 263 & \\
\hline
\end{tabular}

*: species not found associated with Croton trees. 
Table (2). Species richness of the collected spiders inhabiting Croton, May 2009 - April 2010

\begin{tabular}{|c|c|c|c|c|c|c|}
\hline Families \& Species & $\hat{0}$ & 우 & $\mathrm{J}$ & $\Sigma$ & Total & $\%$ \\
\hline Philodromidae & & & & & \multirow{4}{*}{66} & \multirow{4}{*}{21.71} \\
\hline Thanatus albini & 1 & 1 & - & 2 & & \\
\hline Philodromus sp. & 9 & 14 & 40 & 63 & & \\
\hline Tibellus sp.* & 1 & - & - & 1 & & \\
\hline \multicolumn{5}{|l|}{ Araneidae } & \multirow{6}{*}{65} & \multirow{6}{*}{21.38} \\
\hline Larinioides cornutus & 15 & 5 & - & 20 & & \\
\hline Agalenatea redii ${ }^{*}$ & 1 & - & - & 1 & & \\
\hline Araneus sp. & 6 & 6 & 1 & 13 & & \\
\hline Neoscona $\mathrm{sp}$. & 4 & 8 & - & 12 & & \\
\hline Unidentified species & - & - & 19 & 19 & & \\
\hline \multicolumn{5}{|l|}{ Theridiidae } & \multirow{2}{*}{64} & \multirow{2}{*}{21.05} \\
\hline Kochiura aulica & 17 & 20 & 27 & 64 & & \\
\hline \multicolumn{5}{|l|}{ Salticidae } & \multirow{6}{*}{37} & \multirow{6}{*}{12.17} \\
\hline Thyene imperialis & 2 & 3 & 8 & 13 & & \\
\hline Hasarius adansoni & 2 & 2 & 2 & 6 & & \\
\hline Salticus propinquus ?* & - & - & 1 & 1 & & \\
\hline Ballus sp. & 2 & 1 & 3 & 6 & & \\
\hline Unidentified species* & - & 3 & 8 & 11 & & \\
\hline \multicolumn{5}{|l|}{ Miturgidae } & \multirow{2}{*}{33} & \multirow{2}{*}{10.85} \\
\hline Cheiracanthium sp. & 4 & 5 & 24 & 33 & & \\
\hline \multicolumn{5}{|l|}{ Uloboridae } & \multirow{3}{*}{13} & \multirow{3}{*}{4.28} \\
\hline Uloborus walckenaerius & 1 & 4 & - & 5 & & \\
\hline Uloborus sp.* & 3 & 5 & - & 8 & & \\
\hline \multicolumn{5}{|l|}{ Lycosidae } & \multirow{5}{*}{13} & \multirow{5}{*}{4.28} \\
\hline Trochosa sp. & 1 & - & 3 & 4 & & \\
\hline Pardosa sp.- & - & 1 & - & 1 & & \\
\hline Allocosa sp. & - & 3 & 3 & 6 & & \\
\hline Unidentified species & - & - & 2 & 2 & & \\
\hline \multicolumn{5}{|l|}{ Thomisidae } & \multirow{3}{*}{6} & \multirow{3}{*}{1.97} \\
\hline Thomisus spinifer & 1 & - & - & 1 & & \\
\hline Thomisus sp. & 2 & 3 & - & 5 & & \\
\hline Dictynidae & \multicolumn{4}{|c|}{. } & \multirow{2}{*}{5} & \multirow{2}{*}{1.64} \\
\hline Nigma sp.* & 3 & 1 & 1 & 5 & & \\
\hline \multicolumn{5}{|l|}{ Linyphiidae } & 2 & 0.66 \\
\hline Erigone dentipalpis* & 1 & 1 & - & 2 & & \\
\hline Total & 76 & 86 & 142 & 304 & 304 & \\
\hline
\end{tabular}

*: species not found associated with Lantana shrubs.

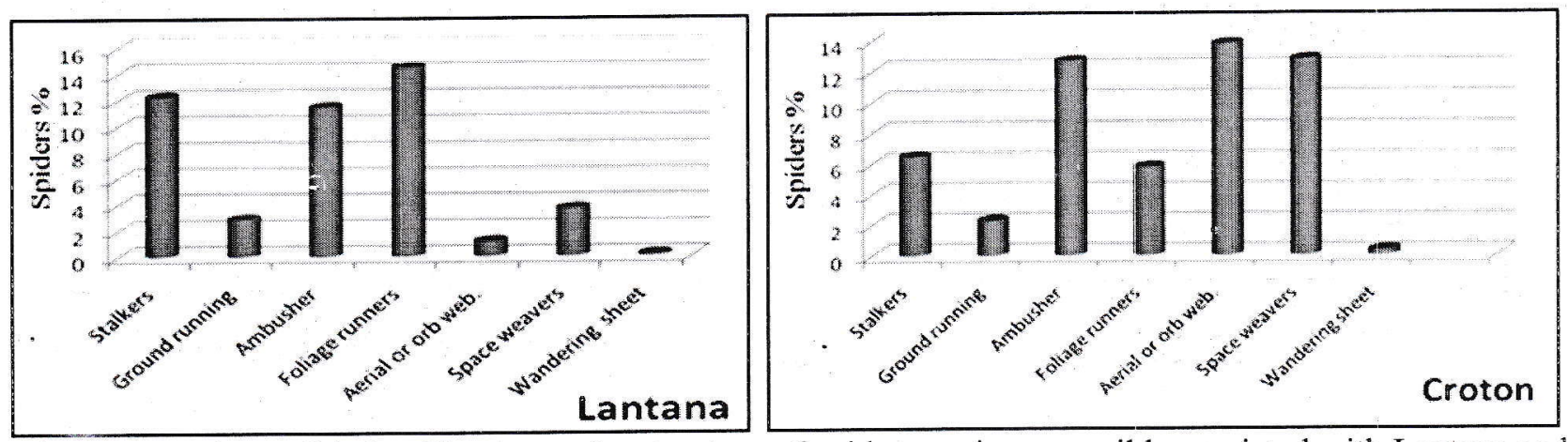

Fig. (1): Foraging guild classification and percentage of spider species per guild associated with Lantana and Croton plants. 


\section{Species richness:}

Among the 34 species of spiders recorded during this study, 27 species of 10 families were recorded on Croton trees and 32 species of 13 families on Lantana hedges. All families except Oxyopidae, Dysderidae, and Hersiliidae were noted on both plants. A total of 13 species had common occurrence in both plants. The dominant species was Cheiracanthium sp. represented by 33 \&81individuals on Croton and Lantana, respectively, followed by Philodromus sp. (63 \& 44) and then Kochiura aulica (64 \& 19) on Croton and Lantana, respectively.

In addition to species composition, foraging guild composition also significantly differed among sampling sites.

\section{Spider guild composition (Functional groups):}

The collected spiders can be divided into seven functional guilds (Table 3, Fig. 1) based on their foraging behaviour in the field as described by Uetz et al. (1999),

\section{Hunting spiders:}

- Stalkers: Salticidae, Oxyopidae.

- Ground runners: Lycosidae, , and Dysderidae.

- Ambushers: Philodromidae, and Thomisidae.

- Foliage runners: Miturgidae, and Hersiliidae.

\section{Web building spiders (aerial web):}

- Orb web: Araneidae, and Uloboridae.

- Space weavers: Theridiidae and Dictynidae.

- Wandering sheet: Linyphiidae.

The foliage runner, stalker and ambusher spider guilds were the dominant feeding guilds on Lantana representing $14.5,12.3 \& 11.5 \%$, respectively of the total collected spiders. While the orb web spiders, the space weavers, and the ambushers were the dominant feeding guilds on Croton representing $13.8,12.8 \& 12.7 \%$, respectively of the total collected spiders and had the highest species richness.

\section{Faunal similarity of spiders:}

Species richness of spiders collected from Croton (304 individuals) was greater than that of Lantana (263), while the number of spider species greater in Lantana (27 species) than that of Croton (22). Among the 34. genera obtained, 13 were associated with Lantana only and 7 with Croton, while 15 species were recorded associated with both hosts (Table 3). To allow a comparison between the habitats of the two hosts, Sørensen's Quotient of similarity (QS) for both hosts was calculated. It is concluded that the two plants are semi-similar as they recorded $60 \%$ of similarity.

\section{Monthly fluctuation of spider populations:}

Total monthly counts of spiders collected from Croton trees occurred in high abundance in early summer during May (69 individuals followed by June (51), while the lowest numbers (11 and 10) were recorded during February and March, respectively, (Fig.2). Respective numbers in Lantana plants were 33 and 31 individuals in May and June, while the lowest numbers $(11 \& 13)$ were recorded during December, January and February. These results were confirmed by Mushtaq et al. (2000) who recorded that maximum numbers of foliage spider species were recorded in the monthly sample of May with no significant differences among locations. Similar results were reported by Bogya and Markó (2008) who found that spiders showed one population peak in spring time.

\section{Rank abundance of spider families:}

The collected spiders were presented by families in Table 4 to show their abundance. Five families contained $85.17 \%$ of the total collected spiders i.e. Miturgidae, Philodromidae, Salticidae, Theridiidae and Araneidae. The greatest number of collected individuals presented family Miturgidae (114 individuals), then Philodromidae (112), and Salticidae (104). Families Theridiidae (83 individuals) and Araneidae (70) were ranked the fourth and fifth, respectively.

The biodiversity of spiders associated with the two ornamental plants is compared using Shannon Wiener "H"' and Simpson "S" Indices of diversity (Table 5). The cover plantation of Croton trees varied in their species richness and recorded the highest population of total number (304) individuals larger than those obtained of Lantana shrubs. Its ecosystem was made of 10 families, 21 genera and at least 21 species; while the species richness of Lantana plant were 263 individuals belonged to 13 families, 25 genera and at least 27 species.

\section{Species diversity:}

Using Shannon Wiener Index, the biodiversity index calculation indicated that Croton was the most diverse. The species richness of spiders of different families and their equitability (evenness) were higher in Croton trees than that of Lantana shrubs which could be related to the type of plant dense vegetation and higher humidity produced from the lake near the plant.

According to Simpson Index which is a measure of dominance (responsive to changes for the most 
Table (3): Guild classification of spider taxa associated with Lantana and Croton plants

\begin{tabular}{|c|c|c|c|c|c|c|c|c|c|c|}
\hline \multirow{2}{*}{$\begin{array}{c}\text { Families and } \\
\text { Foraging guild }\end{array}$} & \multicolumn{3}{|c|}{ Lantana } & \multirow{2}{*}{$\%$} & \multicolumn{3}{|c|}{ Croton } & \multirow{2}{*}{$\%$} & \multirow{2}{*}{$\begin{array}{c}\text { Com. } \\
\text { sp. }\end{array}$} & \multirow{2}{*}{$\begin{array}{l}\text { Tot. } \\
\text { sp. }\end{array}$} \\
\hline & Sp. rich & No. sp. & Uni sp. & & Sp. rich & No. sp. & Uni.sp. & & & \\
\hline \multicolumn{11}{|l|}{ 1. Stalkers } \\
\hline Salticidae & 67 & 12 & 9 & \multirow[t]{2}{*}{12.3} & 37 & 4 & 1 & \multirow[t]{2}{*}{6.5} & 3 & 13 \\
\hline Oxyopidae & 3 & 1 & 1 & & - & - & - & & 0 & 1 \\
\hline \multicolumn{4}{|l|}{ 2. Ground running } & \multirow{3}{*}{2.9} & . & & & \multirow{3}{*}{2.3} & & \\
\hline Lycosidae & 13 & 3 & - & & 13 & 3 & - & & 3 & 3 \\
\hline Dysderidae & 4 & 1 & 1 & & - & - & - & & 0 & 1 \\
\hline \multicolumn{11}{|l|}{ 3. Ambushers } \\
\hline Philodromidae & 46 & 2 & - & \multirow[t]{2}{*}{11.5} & 66 & 3 & 1 & \multirow[t]{2}{*}{12.7} & 2 & 3 \\
\hline Thomisidae & 19 & 2 & - & & 6 & 2 & - & & 2 & 2 \\
\hline \multicolumn{11}{|l|}{ 4. Foliage runners } \\
\hline Miturgidae & 81 & 1 & - & \multirow[t]{2}{*}{14.5} & 33 & 1 & - & \multirow[t]{2}{*}{5.8} & 1 & 1 \\
\hline Hersiliidae & 1 & 1 & 1 & & - & - & - & & 0 & 1 \\
\hline \multicolumn{11}{|l|}{ 5. Aerial or orb web } \\
\hline Araneidae & 5 & 1 & - & \multirow[t]{2}{*}{1.2} & 65 & 4 & 3 & \multirow[t]{2}{*}{13.8} & 1 & 4 \\
\hline Uloboridae & 2 & 1 & - & & 13 & 2 & 1 & & 1 & 2 \\
\hline \multicolumn{11}{|l|}{ 6. Space weavers } \\
\hline Theridiidae & 19 & 1 & - & \multirow[t]{2}{*}{3.7} & 64 & 1 & - & \multirow[t]{2}{*}{12.8} & 1 & 1 \\
\hline Dictynidae & 2 & 1 & - & & 5 & 1 & - & & 1 & 1 \\
\hline \multicolumn{11}{|l|}{ 7. Wandering sheet } \\
\hline Linyphiidae & 1 & 1 & 1 & & 2 & 1 & 1 & & 0 & 2 \\
\hline . $\quad$ Total & 263 & 28 & 13 & & 304 & 22 & 7 & & 15 & 35 \\
\hline
\end{tabular}

Sp. rich. $=$ Species richness, No. sp. $=$ Number of species, Uni. sp. = Unique species,

Com. $\mathrm{sp} .=$ Common species, Tot. $\mathrm{sp} .=$ Total species.

Table (4). Rank abundance of spider family in Orman garden, May 2009 - April 2010

\begin{tabular}{lcccc}
\hline \multicolumn{1}{c}{ Families } & Lantana & Croton & Total & $\%$ \\
\hline Miturgidae & 81 & 33 & 114 & 20.10 \\
\hline Philodromidae & 46 & 66 & 112 & 19.75 \\
\hline Salticidae & 67 & 37 & 104 & 18.34 \\
\hline Theridiidae & 19 & 64 & 83 & 14.64 \\
\hline Araneidae & 5 & 65 & 70 & 12.34 \\
\hline Lycosidae & 13 & 13 & 26 & 4.58 \\
\hline Thomisidae & 19 & 6 & 25 & 4.41 \\
\hline Uloboridae & 2 & 13 & 15 & 2.64 \\
\hline Dictynidae & 2 & 5 & 7 & 1.23 \\
\hline Dysderidae & 4 & 0 & 4 & 0.70 \\
\hline Oxyopidae & 3 & 0 & 3 & 0.53 \\
\hline Linyphiidae & 1 & 2 & 3 & 0.53 \\
\hline Hersiliidae & 1 & 0 & 1 & 0.18 \\
\hline Total & 263 & 304 & 567 & \\
\hline & & & &
\end{tabular}

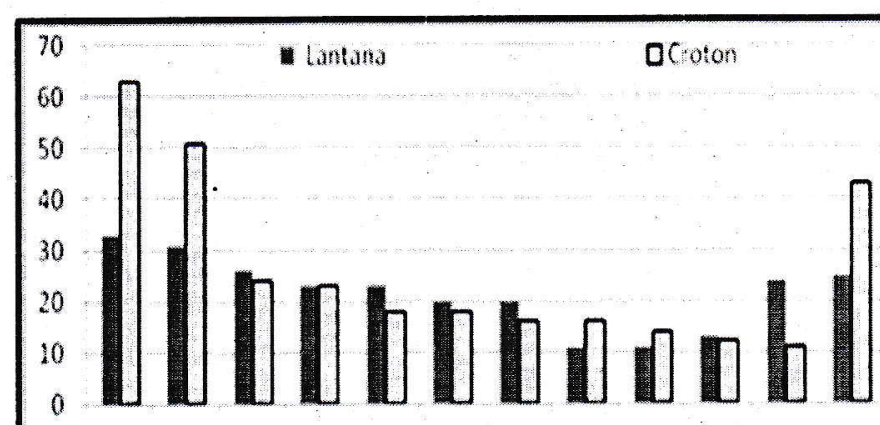

May June July Aug Sept. Oct. Nov. Dec. Jan Feb March Aprt

Fig.(2). Total numbers of spiders collected monthly May 2009 and April 2010 from Lantana and Croton plants in Orman garden.

Table (5). Comparison of community structure of collected spiders from Lantana and Croton plants.

\begin{tabular}{|c|c|c|c|c|c|c|c|c|}
\hline \multirow{2}{*}{ Families } & \multicolumn{4}{|c|}{ Lantana } & \multicolumn{4}{|c|}{ Croton } \\
\hline & Species richness & $\mathrm{H}^{\top}$ & Species evenness & $\mathrm{S}$ & Species richness & $\mathrm{H}^{\prime}$ & Species evenness & $\mathrm{S}$ \\
\hline Philodromidae & 46 & 0.18 & 1.197 & 0.9 & 66 & 0.21 & 1.234 & 0.9 \\
\hline Salticidae & 67 & 1.73 & 5.315 & 0.31 & 37 & 1.15 & 3.158 & 0.25 \\
\hline Miturgidae & 81 & 1 & 2.718 & 1 & 33 & 1 & 2.718 & 1 \\
\hline Theridiidae & 19 & 1 & 2.718 & 1 & 64 & 1 & 2.718 & 1 \\
\hline Araneidae & 5 & 0.67 & 1.954 & 0.52 & 65 & 1.4 & 4.055 & 0.25 \\
\hline Lycosidae & 13 & 1.34 & 3.819 & 0.25 & 13 & 1.2 & 3.32 & 0.33 \\
\hline Thomisidae & 19 & 0.65 & 1.915 & 0.51 & 6 & $0.4 j$ & 1.568 & 0.7 \\
\hline Uloboridae & 2 & 1 & 2.718 & 1 & 13 & 0.7 & 2.014 & 0.5 \\
\hline Dictynidae & 2 & 1 & 2.718 & 1 & 5 & 1 & 2.718 & 1 \\
\hline Dysderidae & 4 & 1 & 2.718 & 1 & 0 & 0 & 0 & 0 \\
\hline Oxyopidae & 3 & 1 & 2.718 & 1 & 0. & 0 & 0 & 0 \\
\hline Linyphiidae & 1 & 1 & 2.718 & 1 & 2 & 1 & 2.718 & 1 \\
\hline Hersiliidae & 1 & 1 & 2.718 & 1 & 0 & 0 & 0 & 0 \\
\hline
\end{tabular}


dominant species), it was found that Lantana shrubs included the highest number of dominant species.

This study indicated the influence of vegetation structure on the diversity of resident spider community. Lantana shrubs seemed to have a higher amount of diversity than Croton trees because it had the greatest number of species, but the evenly spread abundance of species found in Croton trees made it more diverse. The biodiversity index calculation indicated that Croton was the most diverse and contradicted the initial expectation that Lantana shrubs were more diverse.

The high species diversity of spiders in Croton trees could be attributed to the dense cover of plants and the marsh near the trees which sustained a high faunal diversity. While the high variety of species in Lantana shrubs, might be attributed to the high diversity of cactus and succulent plants extended along the hedge of Lantana. This result agreed with Swarupanandan et al. (2000) who assumed that a high floral diversity sustained a high faunal diversity. Also the structure of Lantana vegetation affected species variety as Uetz (1991) suggested that the structure vegetation of shrubs was more complex and could support a more diverse spider community.

A comparison of guild composition could provide insight into the effect of habitat alteration and disturbance on arthropod biodiversity (Stork, 1987). This observation is in conformity with my result which showed the responses of spider abundances to different structural vegetation. So, foliage runner spiders and stalkers were the dominant guild on Lantana shrubs which had few branches. This is in accordance with De Souza \& Martins (2005) who proved that foliage-runners constituted the dominant guild on Desmanthus virgatus and Banksia gardneri, which had few branches; and they suggested that branch architecture was the most important factor determining the abundance of plant-dwelling spiders in the study area independently of branch biomass, leaf surface area or texture. While Croton plants have few ground runners and stalkers but rather high abundance of aerial-orb web and space weavers. This pattern probably resulted because it is a good microhabitat for web construction due to the dense vegetation. Wandering sheet guild was the least frequent in both plants.

Moreover, in the two studied communities, the most common species were Cheiracanthium sp. $(20.1 \%)$ of the total samples followed by
Philodromus sp. represented by $(18.9 \%)$, then Kochiura aulica (14.6\%). This result is in good agreement with Perez-Guerrero et al. (2009) who recorded the most abundant species in organic cotton crops was Cheiracanthium sp. followed by Philodromus sp.

This work is a first step in understanding the spiders' diversity and their abundance in the Orman garden. Further study will certainly reveal much more species of spiders. However, it is hoped that this study will be helpful to some extent for future workers in Egypt, and will extend research to build upon the checklist and to continue the study of the Egyptian spider fauna.

\section{ACKNOWLEDGEMENT}

The authoress expresses her sincere gratitude to Mr. Hisham K. El-Hennawy, the expert in Arachnology for revising the identification of spiders. Also, sincere thanks are extended to Noha El-Sayed El-Sharkawy my colleague, in the Vegetable Mites Department, P.P.R.I., A.R.C. for her help in collecting specimens.

\section{REFERENCES}

El-Hennawy, H.K. 2006. A list of Egyptian spiders (revised in 2006). Serket, 10(2): 65-76.

Habashy, N.H.; Ghallab, M.M. and Rizk, M.A. 2005. Spider populations associated with different types of cultivation and different crops in Fayoum Governorate, Egypt. Serket, 9(3): 101-107.

Hendawy, A.A. and Abul-Fadl, H.A.A. 2004. Survey of true spider community and its response to chemical and organic fertilizers in the Egyptian corn field. Proceedings of $1^{\text {st }}$ Arab Conference for Applied Biological pest control, Egypt. J. Biol. Pest Cont., 14(1): 231-235.

Hermann D.J.; Bailey, D.; Hofer, G.; Herzog, F. and Schmidt-Entling, M.H. 2010. Spiders associated with the meadow and tree canopies of orchards respond differently of habitat fragmentation. Landscape Ecol., 25: 1375-1384.

Huber, B.A. 2005. Key to families adapted from "Spinnen Mitteleuropas" Museum Koenig, Bonn.http://www.unibonn.de/ bhuber1/spider_key/ARANEAE.html.

Hussein, A.M. 1999. Seasonal abundance and daily activity patterns of spider fauna in some vegetable crops in Menoufiya governorate, Egypt. J. Agric. Res., 77(2): 677-690.

Hussein, A.M.; Hassan, M.F. and Ragab, N.F. 2003. Biological aspects of Anelosimus aulicus (C.L. 
Koch, 1838) (Arachnida: Araneae: Theridiidae). Serket, 8(4): 129-134.

Kaston, B.J. 1978. How to know spiders. 272pp, $3^{\text {rd }}$ edit. Wm. C Brown company Publishers.

Levi, H.W. 2002. Keys to the genera of araneid orb weavers (Araneae, Araneidae) of the Americas. $J$. Arachnol., 30(3): 527-562.

Ludwig, J. A. and Reynolds, J. F. 1988. Statistical Ecology: A primer on methods and computing. New York, 337pp.

Mahmoud, M. F. R.; Rahil, A. A. R. and Mohammad, M. S. A. 2011. Impact of different pesticides on spider species of four families. . Acarines, 5: 51-63.

Mushtaq, Shakila; Hadait, Saadia and Ali, Liaqut 2000. Diversity and relative abundance of spiders of date palm. Groves International Journal of Agriculture \& Biology, 2(1-2): 52-54.

Nestle, D.; Dickschen, F. and Altieri, M.A. 1993. Diversity patterns of soil macro-Coleoptera in Mexican shaded and unshaded coffee agroecosystems in indication of habitat perturbation. Biodiversity and conservation, 2: 70-78.

Oger, P. 2002. Les Araignées de Belgique et de France, on-line at http://arachno.piwigo.com/ index.php?/categories

Ovtsharenko, V. and Tanasevitch, A. 2002 a. A key to spider families. American Museum of Natural History, on-line at http://research.amnh.org/iz /blackrock $2 /$ key.htm

Ovtsharenko, V. \& Tanasevitch, A. 2002b. Family Lycosidae (wolf spiders). American Museum of Natural History, on-line at http://research. amnh.org/iz//blackrock2/families/lycosidae.htm

Ovtsharenko, V. and Tanasevitch, A. 2002 c. Family Salticidae (jumping spiders). American Museum of Natural History, on-line at http://research. amnh.org/iz/blackrock2/families/salticidae.htm

Perez-Guerrero, S.; Tamajon, R.; Aldebis, H. and Vargas-Osuna, E. 2009. The spider community in organic cotton crops in southern Spain. Rev. Colomb. Entomol., 35(2): 168-172.

Platnick, N.I. 2012. The World Spider Catalog, version 12.5. American Museum of Natural History, online at http://research.amnh.org /iz/spiders/catalog.

Prószyński, J. 2003. Salticidae genera of Levant (Israel and Neighboring Countries) http://salticidae.org/salticid/diagnost/keys$\mathrm{sal} /$ levant.htm

Ragab, N.F. 2003. Studies on some arthropods inhabiting cucurbits and beans. M.Sc. Thesis, Fac. Agric., Cairo Univ. 105pp.

Sallam, G.M. 2002. Studies on true spiders in Egypt. Ph.D. Thesis, Fac. Agric., Cairo Univ. 144pp.

Sallam, G.M.; Abdel-Azeim, N.A.I. and El-Kawas, H.M.G. 2010. Biodiversity of spiders associated with cotton and maize in Sharkeya governorate with a special reference to the spider Kochiura aulica (Koch). Acarines, 4: 67-71.

Sørensen, T. 1948. A method of establishing groups of equal amplitude in plant sociology based on similarity of species and its application to analyses of the vegetation on Danish commons. Biologiske Skrifter/Kongelige Danske Videnskabernes Selskab, 5: 1-34.

Stork, N.E. 1987. Guild structure of arthropods from Bornean rain forest trees. Ecol. Ent., 12: 69-80.

Sudhikumar, A.V.; Mathew, M.J.; Sunish, E. and Sebastian, P.A. 2005. Seasonal variation in spider abundance in Kuttanad rice agroecosystem, Kerala, India (Araneae). Acta zoologica bulgarica, Suppl., 1: 181-190.

Swarupanandan K.; Sasidharan, N.; Chacko, K.C. and Basha, S.C. 2000. Studies on the Shola Forests of Kerala. Kerala Forests Research Institute research report, $158 \mathrm{pp}$.

Uetz, G.W.; Halaj, J. and Cady, A.B. 1999. Guild structure of spiders in major crops. J. Arachnol., 27(1): 270-280. 